are perhaps three dozen in the town and only two to $m y$ knowledge have had any instruction. I have proposed at different times to some of my confrères that we should bring the midwives together, instruct them in the use of antiseptics, giving each a certificate and extending our help and support to them. To those who refused (if any) we would simply say that they were acting at their peril and had not our cognizance and moral support.

Some of $\mathrm{my}$ confrères think the plan feasible, others fear it would not receive sufficient support all round. I feel confident I can get all to join in giving me their help, though probably some would refuse to take or, rather, neglect to take any active part. Fearing a failure from the above cause I have thought that could we get the initiative to come from outside the profession our position would be much strengthened, and I have little doubt but that we could soon get a strong party of ladies of influence and intelligence to make a move. I do not wish to trouble you with detail and I have also a feeling that you will say this is a subject which requires treatment by higher powers, \&c. In reply to such a suggestion I would say that it is a severe trial to attend at the bedside of strong young women in the prime of life feeling that you are comparatively helpless and knowing that the complaint which is killing them is one that might have been prevented. I say it is a severe trial to wait with patience till the powers that be come to your aid, and it is much harder still if there is any chance of success by one's own efforts. If you will kindly let me know what you think of the scheme I will be very grateful. Hoping I have made it sufficiently clear, I am, Sirs, yours faithfully,

Heywood, Lancs, Jan. 29th, 1898.

ThOMAS LAIRD.

** So far from advising practitioners to wait for the action of higher powers we are always urging them to deal with such matters for themselves as promptly as possible. We think that such a meeting of the medical men of the locality would be a most sensible proceeding and do not see how anything but good could come of it. It seems to us that proper nursing with antiseptic precautions by fit people under the ægis of the medical profession would follow, and we do not think a better sequence could be desired. The success of the scheme depends on the ananimity of the profession in the neighbourhood.-ED. I.

\section{"THE OPERATIVE TREATMENT OF CLEFT PALATE."}

\section{To the Editors of THE LANCET.}

SIRS, - I read with much interest Mr. Edmund Owen's clinical lecture under the above title in THE LANCET of Jan. 29th and was pleased to learn that he practises in favourable cases closure of the palate during infancy. The chief object, I take it, in closing a cleft palate is to render the powers of speech more perfect than they otherwise would be and if the operation is postponed (as usually recommended in surgical text-books) until the third year of life or later the child by that time has probably learnt to talk and necessarily to talk badly, a habit once acquired very difficult to overcome completely.

At a recent meeting of the Liverpool Medical Institation I brought forward several children whose palates I had closed some three or four years ago. Their ages at the date of operation varied from eight months to eighteen months and the clefts involved the soft and part of the hard palate. These children now talk in a perfectly natural manner, it being quite impossible to detect from their speech that they ever had cleft palates. Mr. Owen and other surgeons have doubtless had a similar experience.

I am, Sirs, yours faithfully,

R. W. MURRAY, F.R.C.S Eng.

Surgeon to the Liverpool Infirmary for Children.

Liverpool, Jan. 31st, 1898.

\section{THE NOTIFICATION OF INFLUENZA.}

\section{To the Editors of THE LANOET.}

Sirs,-May I ask you why no means are taken to check the spread of the most contagious, widely - spread, and formidable epidemic-viz., influenza? One cannot take up a paper or consult any friend without seeing or hearing of someone being either ill or dead or permanently affected by that dreadful disease. It is quite a common case to hear invalids say, "Never the same since the influenza." From 50 to 100 deaths weekly in London are directly due to influenza, besides those who recover, very many of them being permanently invalided, is no small matter. Those recovering from influenza (which is most undoubtedly highly contagious and often contracted severely by almost momentary contact with very slight cases) are allowed to go travelling about, to concerts, theatres, churches, and elsewhere; while those recovering from scarlet fever, measles, and suchlike complaints would be heavily fined (which has had a very desirable effect). Why cannot this fearful scourge be included in the Notification of Infectious Diseases Act and treated accordingly? I expect that will be the only way of checking the vast amount of misery and loss of life this disease causes and the sooner it is adopted the better. I am, Sirs, yours faithfully,

Worcester, Jan. 31st, 1898. W. WooDWARD, IM. D. St. And.

\section{AN APPEAL FOR ASSISTANCE. Zo the Editors of THE LANCET.}

SIRs, - I venture to appeal through the columns of THE LANCET to the charitable of our profession for financiai aid in a most deserving case. Mrs. Tickler, of Cavendish. road, Harringay, is both aged and infirm; she is the widow of a Lincolnshire surgeon, who died about ten years ago, leaving her but poorly off, so that she has practically great difficulty in making ends meet. Her two daughters givo her such aid as they can, but their occupation is not very constant or remunerative.

I shall be pleased to start the list by a donation of two guineas and also to act as Treasurer, should yon wish it, due acknowledgment being made through your columns. I am, Sirs, yours faithfully,

2A, Harringay-gardens, Green Lanes, Feb. 1 st, 1898. JOHN HUTTON.

\section{"TREATMENT OF PNEUMONIA BY INHALATIONS OF OXYGEN GAS."}

\section{To the Editors of THE IUANORT.}

SIRS,-The case reported by Dr. Alex. M. Erskine in THE LANCET of Jan. 29th is not without interest as showing what can and what cannot be done by the inhalation of oxygen, but I think that the result might have been predicted without making the experiment. If the patient had been promptly and sufficiently bled-say, 15 or 20 oz., repeated if necessaryinstead I am confident that much better results would have been attained and more easily. The woman's serious condition would have been speedily relieved and in all probability she would have recovered, being "a strong, healthy woman." I could cite several instances in corroboration of what I say and I believe that nothing is so efficacious as venesection. - $1 \mathrm{am}$, Sirs, yours faithfully,

Elizabeth-street, S.W., Jan. 29th, 1898

$$
\text { F. LUCAS BENHAM, M.D., M.R.C.P. Lond. }
$$

\section{"A CASE OF JEALOUSY."}

\section{To the Editors of THE LANOHT.}

SiRs, - The case of morbid jealousy so graphically described in THE LANCET of Jan. 22nd by Dr. William O'Neill opens up many points of sociological, psychological, and medical interest. Jealousy, it should be noted, does not arise out of physical love alone, being common in children and is grown-ups unsusceptible of this form of love. In the unmarried it seems to be about equally developed in either sez, but after marriage it is much more pronounced among the women, and this not because they have a greater disposition to it but because the provocation is greater in their case. As I have pointed out in $\mathrm{my}$ "Differences in the Nerrous Organisation of Man and Woman," man is descended from polygamous ancestors and to pretend that he does not still 